\title{
Purification and Properties of NADPH-Linked L-Sorbose Reductase from Gluconobacter melanogenus N44-1
}

\author{
Teruhide Sugisawa, ${ }^{\dagger}$ Tatsuo Hoshino and Akiko Fujiwara \\ Department of Applied Microbiology, Nippon Roche Research Center, \\ 200, Kajiwara, Kamakura, Kanagawa 247, Japan
}

Received January 23, 1991

\begin{abstract}
NADPH-Linked L-sorbose reductase from the cytosol fraction of Gluconobacter melanogenus N44-1, which is a 2-keto-L-gulonic acid producer from L-sorbose or D-sorbitol, was purified about 500-fold by DEAE-Cellulose, Blue Sepharose, and DEAE-Sepharose column chromatographies. The purified enzyme was entirely homogeneous on polyacrylamide gel and SDS gel electrophoresis. NADPH and NADP were specifically required for the reduction and oxidation of the substrate, respectively. The apparent molecular weight was 60,000 by Sephadex G-200 column chromatography, and that of its subunit was 60,000 by SDS-gel electrophoresis. The $\mathrm{pH}$ optimum for the reduction of L-sorbose and D-fructose was 7.0. The $\mathrm{pH}$ optimum for the oxidation of D-sorbitol to L-sorbose and D-mannitol to $\mathrm{D}$-fructose was $10.0-10.5$.
\end{abstract}

As previously reported, ${ }^{1)}$ we have developed a fermentation process that produces 2-ketoL-gulonic acid (2KGA) from L-sorbose and Dsorbitol via $\mathrm{L}$-sorbosone by a mutant derived from $G$. melanogenus IFO 3293, and isolated the two key enzymes of membrane-bound L-sorbose dehydrogenase ${ }^{2\}}$ and NAD(P)-dependent L-sorbosone dehydrogenase ${ }^{3)}$ found through the study of the metabolic pathway for $2 \mathrm{KGA}$ formation. ${ }^{4)}$

When $G$. melanogenus UV10 and its mutants ${ }^{1)}$ were used in $2 \mathrm{KGA}$-fermentation process, a substantial amount of L-sorbose fed to the medium was consumed to yield carbon dioxide without contributing to $2 \mathrm{KGA}$ formation. The $\mathrm{CO}_{2}$ evolved from L-sorbose by the $2 \mathrm{KGA}$ high producer was mainly via the pentose phosphate pathway. ${ }^{5)}$ This shows that L-sorbose is metabolized to D-sorbitol besides the oxidation of L-sorbose to L-sorbosone for the main pathway to produce $2 \mathrm{KGA}$. In addition, we showed ${ }^{4)} \mathrm{D}$-sorbitol was produced from L-sorbose by the enzyme contained in the cytosol fraction of $2 \mathrm{KGA}$ producers. If we could obtain a mutant such that the reducing activity of L-sorbose to D-sorbitol was decreased, further improvement of $2 \mathrm{KGA}$ could be expected.

The enzyme reducing L-sorbose (we say L-sorbose reductase) is found in various Gluconobacters as an NADP-linked enzyme catalyzing the L-sorbose-D-sorbitol conversion, but the enzyme has not been isolated.

As the characterization of the enzyme reducing L-sorbose in a high $2 \mathrm{KGA}$ producer (G. melanogenus N44-1) was thought to be advantageous to the further improvement of $2 \mathrm{KGA}$ yield, we tried to isolate the $\mathrm{L}$-sorbose reductase.

This report deals with the purification and characterization of NADPH-linked L-sorbose reductase isolated from the cytosol fraction of G. melanogenus N44-1 during study of the mechanism of $2 \mathrm{KGA}$ formation from $\mathrm{L}$ sorbose and D-sorbitol (Fig. 1). ${ }^{4)}$

\section{Materials and Methods}

Chemicals. NADP and reduced NADP were purchased from Oriental Yeast Ind., Co.; D-sorbitol, D-fructose, and D-mannitol, from Nakarai Chemicals, Ltd. 5-Keto-fructose was purchased from Chemical Dynamics Co.; L-Sorbose,

\footnotetext{
† To whom all correspondence should be address.
} 


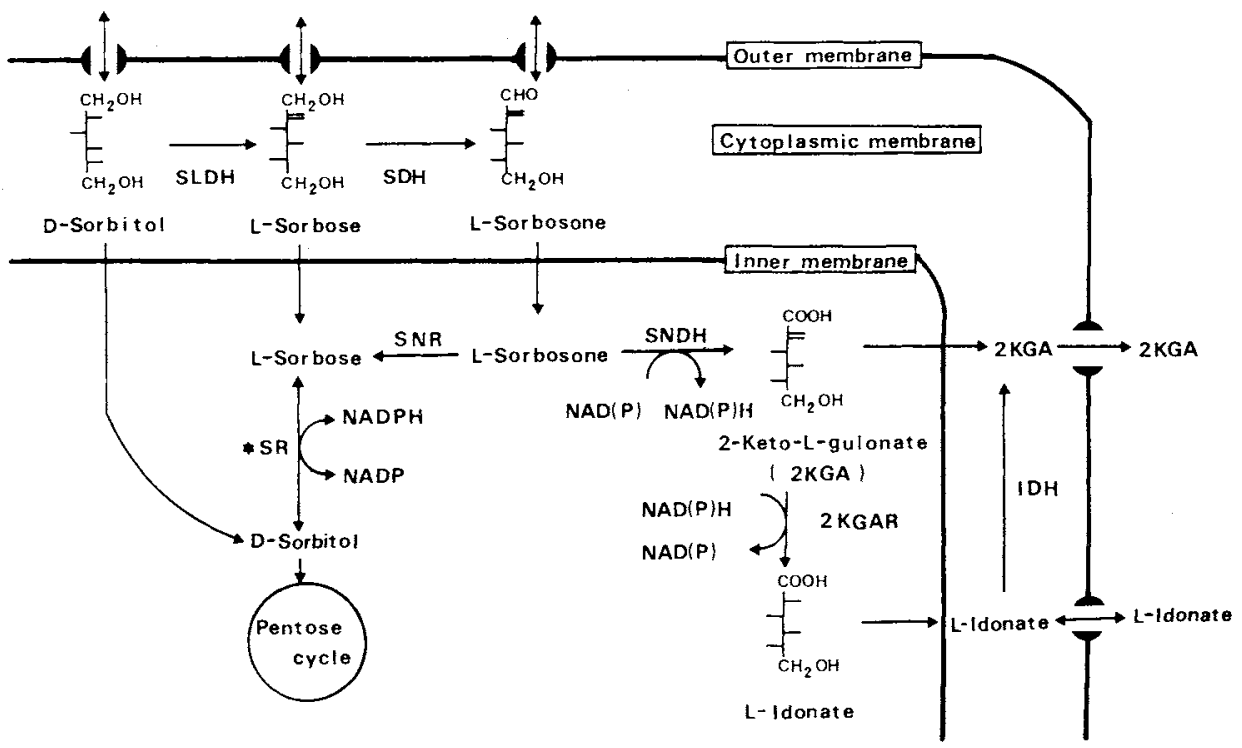

Fig. 1. The Mechanism of 2KGA Production from L-Sorbose and D-Sorbitol in Gluconobacter melanogenus. ${ }^{4)}$ Enzymes in the cytoplasmic membrane: SLDH, D-sorbitol dehydrogenase; SDH, L-sorbose dehydrogenase; IDH, L-idonic acid dehydrogenase.

Enzymes in the cytosol: SNR, L-sorbosone reductase; SNDH, L-sorbosone dehydrogenase; 2KGAR, 2-keto-L-gulonic acid reductase; SR, L-sorbose reductase (described in this paper).

from E. Merck.

DEAE-Cellulose DE-52 was from Whatman, Ltd. and DEAE-Sepharose CL-6B, Blue Sepharose, and Sephadex G-200 were from Pharmacia Fine Chemicals. All other chemicais were reagent grade.

Microorganism. Gluconobacter melanogenus $\mathrm{N} 44-1,{ }^{1)}$ a mutant strain producing large amounts of 2-keto-L-gulonic acid from L-sorbose or D-sorbitol and selected through repeated mutagenesis of G. melanogenus UV10, was used.

Medium and Cultivation. The culture medium consisted of $100 \mathrm{~g}$ of L-sorbose, $15 \mathrm{~g}$ of yeast extract, $2.5 \mathrm{~g}$ of $\mathrm{MgSO}_{4} \cdot 7 \mathrm{H}_{2} \mathrm{O}, 0.5 \mathrm{~g}$ of glycerol, $20 \mathrm{~g}$ of $\mathrm{CaCO}_{3}$, and $1.5 \mathrm{~g}$ of antifoam in one liter of deionized water.

$G$. melanogenus N44-1 was transferred from a potatoagar slant to $5 \mathrm{ml}$ of medium in a test tube and cultivated at $30^{\circ} \mathrm{C}$ for 2 days. One $\mathrm{ml}$ of this culture was transferred to $50 \mathrm{ml}$ of the same medium in a $500-\mathrm{ml}$ shaker flask and cultivated at $30^{\circ} \mathrm{C}$ for 2 days on a rotary shaker $(180 \mathrm{rpm})$.

One hundred $\mathrm{ml}$ of this culture was used as the inoculum for a 3-liter jar fermentor containing 2 liters of the medium. The jar fermentor was operated at $30^{\circ} \mathrm{C}, 500 \mathrm{rpm}$ for agitation, and $0.75 \mathrm{vvm}$ for aeration.

After $42 \mathrm{hr}$ of fermentation, the culture was harvested for the collection of cells. The broth was centrifuged at $1,500 \mathrm{rpm}$ for $10 \mathrm{~min}$ for the removal of calcium carbonate and then at $8,000 \mathrm{rpm}$ for pelleting the cells. The cell cake was washed with $0.85 \% \mathrm{NaCl}$ twice. From 2 liters of broth, we obtained $30 \mathrm{~g}$ (wet weight) of the cells, which was frozen at $-20^{\circ} \mathrm{C}$ until use.

Enzyme assay. The enzyme activity was estimated by measuring the decrease (or increase) in absorbance at $340 \mathrm{~nm}$ due to NADPH. The complete reaction mixture contained $0.25 \mathrm{mmol}$ of L-sorbose, $0.25 \mu \mathrm{mol}$ of NADPH (or NADP) in $50 \mathrm{~mm}$ potassium phosphate buffer, $\mathrm{pH} 7.0$ (or in $50 \mathrm{~mm} \mathrm{Na}{ }_{2} \mathrm{CO}_{3}-\mathrm{NaHCO}_{3}$ buffer, $\mathrm{pH} 10.0$ ) and enzyme solution in a total volume of $0.51 \mathrm{ml}$.

One unit of enzyme activity was defined as the amount of enzyme catalyzing the oxidation (or reduction) of $1 \mu \mathrm{mol}$ of NADPH (or NADP) per minute at $25^{\circ} \mathrm{C}$.

Protein measurement. Protein was measured with a Bio-Rad protein assay kit (Bio-Rad Laboratories) by measuring the absorbance at $595 \mathrm{~nm}$ with catalase as the standard.

Electrophoresis. A 7.5\% polyacrylamide gel and Tris-glycine buffer $(\mathrm{pH}$ 8.3) were used for disc gel electrophoresis as described by Davis. ${ }^{6)}$

SDS gel electrophoresis was done by the methods of Weber and Osborn ${ }^{73}$ and of Weber and Kuter. ${ }^{8}$

\section{Other measurements}

Methods of molecular weight measurement of the enzyme and other methods are referred to in the Results 
section. Products were identified by gas chromatography, high performance liquid chromatography, and thin layer chromatography. ${ }^{1)}$

\section{Results}

\section{Enzyme purification}

All operations were done at $4^{\circ} \mathrm{C}$ to $8^{\circ} \mathrm{C}$, unless otherwise stated. The buffer mentioned in all steps is $10 \mathrm{~mm}$ potassium phosphate $(\mathrm{pH}$ 7.0).

Step 1: Preparation of cytosol fraction. The frozen cells $(20 \mathrm{~g})$ stored at $-20^{\circ} \mathrm{C}$ were thawed and suspended in $80 \mathrm{ml}$ of buffer. The cells were disrupted in the presence of glass beads $(0.1 \mathrm{~mm}$ diameter) with a Dyno Mill homogenizer (Willy, A Bachofen Co., Basle) at 2,000 rpm for $4 \mathrm{~min}$. The cells, debris, and glass beads were removed by centrifugation at $1,800 \times g$ for $10 \mathrm{~min}$. The supernatant was then centrifuged at $100,000 \times g$ for $60 \mathrm{~min}$. The resulting supernatant was dialyzed against 3 liters of the same buffer (changed twice) for $18 \mathrm{hr}$ and is referred to here as the cytosol fraction $(65 \mathrm{ml})$.

Step 2: DEAE-Cellulose column chromatography. The dialyzed enzyme solution $(60 \mathrm{ml})$ was put on a DEAE-Cellulose DE-52 column $(2.5 \times 20 \mathrm{~cm})$, which had been equilibrated with the same buffer. An $\mathrm{NaCl}$ linear gradient ( 0 to $0.2 \mathrm{M}$ ) was added and the enzyme activity was found in the fractions eluted with about $0.075 \mathrm{M}$ $\mathrm{NaCl}$.

The combined active fractions (about $60 \mathrm{ml}$ ) were concentrated to $18 \mathrm{ml}$ with a membrane filter (Amicon PM-10) and dialyzed against the buffer for $5 \mathrm{hr}$.

Step 3: Blue-Sepharose column chromatography. The dialyzed enzyme solution $(20 \mathrm{ml})$ was passed through a Blue-Sepharose CL-6B column $(1.5 \times 15 \mathrm{~cm})$, which had been equilibrated with the buffer.

Step 4: DEAE-Sepharose column chromatography. The active fractions from Step 3 were combined and put on a DEAE-Sepharose CL-6B column $(1.0 \times 50 \mathrm{~cm})$, which had been equilibrated and washed with the buffer. A linear gradient of $\mathrm{NaCl}(0-0.15 \mathrm{M})$ was added to the buffer and the enzyme was eluted at around $0.1 \mathrm{M} \mathrm{NaCl}$. The specific activity of peak fractions (No. 76-78) were almost the same and the fractions were stored separately at $-20^{\circ} \mathrm{C}$.

Purification of the enzyme, summarized in Table I, was approximately 520 -fold with a yield of $23.9 \%$ if the crude enzyme was taken to be $100 \%$.

\section{Properties of purified enzyme}

To investigate the catalytic properties of L-sorbose reductase, the purified enzyme, with a specific activity of 140.8 , was used under the

Table 1. Purification OF L-SORBOSE ReduCtaSE

\begin{tabular}{lcccc}
\hline \multicolumn{1}{c}{$\begin{array}{c}\text { Purification } \\
\text { step }\end{array}$} & $\begin{array}{c}\text { Total } \\
\text { activity } \\
\text { (unit) }\end{array}$ & $\begin{array}{c}\text { Total } \\
\text { protein } \\
\text { (mg) }\end{array}$ & $\begin{array}{c}\text { Specific } \\
\text { activity } \\
\text { (unit/mg) }\end{array}$ & $\begin{array}{c}\text { Yield } \\
(\%)\end{array}$ \\
\hline $\begin{array}{c}\text { Crude enzyme } \\
\quad \text { Cytosol fraction) }\end{array}$ & 282 & 1,032 & 0.27 & 100 \\
$\begin{array}{l}\text { DEAE-Cellulose } \\
\text { Blue-Sepharose }\end{array}$ & 150.5 & 31.2 & 4.83 & 53.4 \\
$\begin{array}{l}\text { DEAE-Sepharose } \\
\text { DEA.8 }\end{array}$ & 67.6 & 0.48 & 140.8 & 23.9 \\
\hline
\end{tabular}

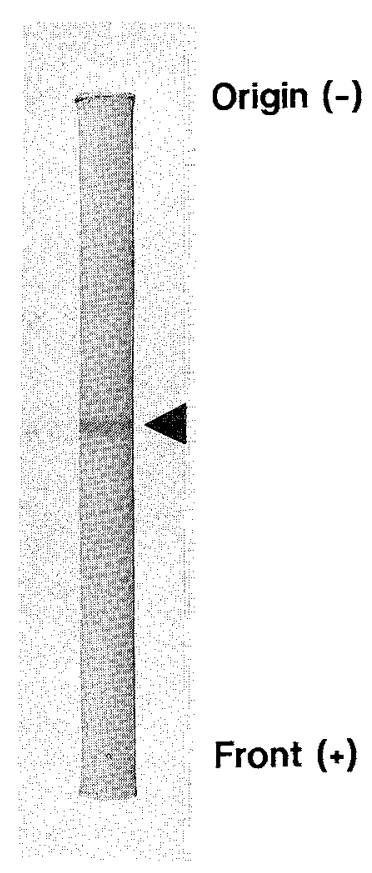

Fig. 2. Polyacrylamide Gel Electrophoresis of L-Sorbose Reductase. 
standard assay conditions unless otherwise stated.

Acrylamide gel electrophoresis. Polyacrylamide disc gel electrophoresis of the purified enzyme obtained from Step 4 is shown in Fig. 2. A single protein band was found, indicating the electrophoretic homogeneity of the preparation.

Molecular weight. The purified L-sorbose reductase was put on a Sephadex G-200 column $(10 \times 500 \mathrm{~mm})$ chromatography and developed with $100 \mathrm{~mm}$ potassium phosphate buffer $(\mathrm{pH}$ 7.0) containing $0.1 \mathrm{M} \mathrm{NaCl}$. The molecular weight of the enzyme was estimated to be $58,000 \pm 1,000$, but about $22 \%$ of the activity
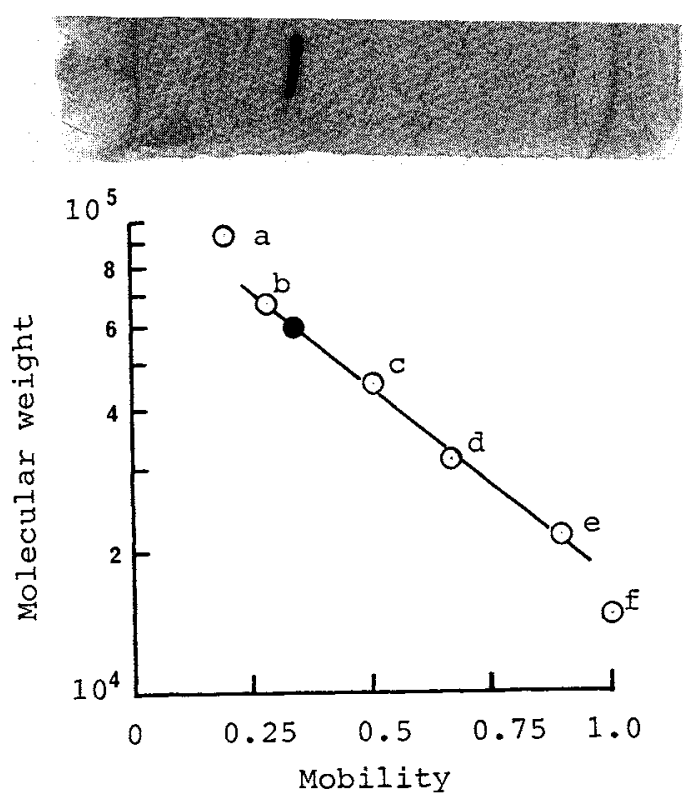

Fig. 3. SDS-Gel Electrophoresis of the Purified NADPHLinked L-Sorbose Reductase.

Purified L-sorbose reductase with a specific activity of 140.8 was used and $3.2 \mu \mathrm{g}$ of protein was put on. The direction of electrophoresis was left to right. After the protein staining with Coomassie brilliant blue $\mathrm{R}-250$ in $7 \%$ acetic acid, the molecular weight of L-sorbose reductase was measured by the plotting mobility versus molecular weight of the standard marker proteins. The position of L-sorbose reductase is marked by a closed circle. The standard marker proteins are indicated alphabetically. a, phosphorylase, mol. wt. 92,500; b, bovine serum albumin, mol. wt. 66,200; c, ovalbumin, mol. wt. 45,000; d, carbonic anhydrase, mol. wt. 31,000; e, soybean trypsin inhibitor, mol. wt. 21,500; f, lysozyme, mol. wt. 14,400. was lost in Sephadex G-200 column chromatography.

The molecular weight of the subunit was estimated by $10 \%(\mathrm{w} / \mathrm{v})$ SDS-polyacrylamide gel electrophoresis. The enzyme preparation gave a single protein band with a molecular weight of $60,000 \pm 1,000$ (Fig. 3). This indicates that $\mathrm{L}$-sorbose reductase from $G$. melanogenus is monomeric.

Effects of $p H$ on activity and stability of the enzyme. The enzyme activity for oxidation and reduction reactions was measured at various $\mathrm{pHs}$. The $\mathrm{pH}$ optimum of the reduction of L-sorbose was about 7.0 and that of the oxidation of D-sorbitol was about 10 (Fig. 4).

The enzyme was stable at $\mathrm{pH} 6.5-7.5$ on incubation at $30^{\circ} \mathrm{C}$ for $30 \mathrm{~min}$ and was stored with little loss of activity at $-20^{\circ} \mathrm{C}$ for a month or more in $0.01 \mathrm{M}$ potassium phosphate buffer, $\mathrm{pH} 7.0$.

Effects of temperature on stability and activity of the enzyme. The effects of temperature on the stability and activity of the enzyme were investigated. Thermostability of the enzyme was tested by a $10-\mathrm{min}$ incubation of the enzyme at various temperatures and then its activity to reduce $\mathrm{L}$-sorbose was tested. The enzyme was stable at up to $50^{\circ} \mathrm{C}-55^{\circ} \mathrm{C}$, but

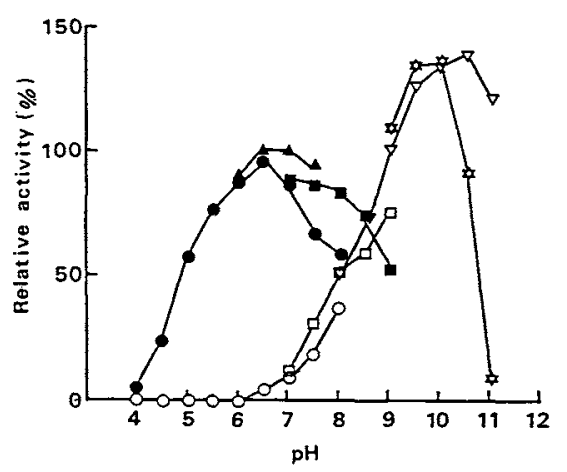

Fig. 4. Effects of $\mathrm{pH}$ on Enzyme Activity.

The purified enzyme was used and the activity was measured under the standard assay conditions using the following buffers: Reduction of L-sorbose: -,$- 0.1 \mathrm{M}$ Mcllvaine buffer; $-\mathbf{A}-, 0.1 \mathrm{M}$ phosphate buffer; $-\mathbf{\square}-$ $0.2 \mathrm{M}$ Tris buffer. Oxidation of $\mathrm{D}$-sorbitol: $-\mathrm{O}-, 0.1 \mathrm{M}$ McIlvaine buffer; $-\square-, 0.2 \mathrm{M}$ Tris buffer; $-\nabla-, 0.1 \mathrm{M}$ $\mathrm{NH}_{4} \mathrm{OH}-\mathrm{NH}_{4} \mathrm{Cl}$ buffer; buffer. 
rapid inactivation occurred when the enzyme was treated at over $60^{\circ} \mathrm{C}$. The highest activity was found at $30^{\circ} \mathrm{C}$.

Inhibitors. The effects of various metals and reagents on L-sorbose reductase activity were studied. The activity was inhibited by $\mathrm{Cu}^{2+}$, $\mathrm{Fe}^{2+}$, and $\mathrm{Ni}^{2+}$ and completely inhibited by

Table II. EFFECTS OF INHIBITORS ON THE ACTIVITY OF L-SORBOSE REDUCTASE

\begin{tabular}{lcc} 
Inhibitor & $\begin{array}{c}\text { Concentration } \\
(\mathrm{mM})\end{array}$ & $\begin{array}{c}\text { Relative activity } \\
(\%)\end{array}$ \\
\hline EDTA & 0.97 & 98 \\
Quinine & 0.49 & 0 \\
& 0.97 & 0 \\
$\mathrm{~N}$-Ethylmaleimide & 0.97 & 81 \\
Sodium azide & 0.97 & 90 \\
Monoiodoacetate $_{\text {PCMB }^{b}}$ & 0.97 & 96 \\
$\mathrm{Na}_{2} \mathrm{HAsO}_{4} \cdot 7 \mathrm{H}_{2} \mathrm{O}$ & 0.19 & 43 \\
Sodium fluoroacetate & 0.97 & 90 \\
Sodium fluoride & 0.97 & 103 \\
$\mathrm{KCN}$ & 0.97 & 103 \\
& 0.19 & 101 \\
& 0.38 & 102
\end{tabular}

a Relative activity is expressed relative to that without the inhibitor.

b $\mathrm{PCMB}, p$-chloromercuribenzoic acid.

Table III. SubStrate Specificity of Purified L-SORBose Reductase

\begin{tabular}{lcc}
\hline \multirow{2}{*}{ Substrate } & \multicolumn{2}{c}{ Relative $\operatorname{activity}^{a}(\%)$} \\
\cline { 2 - 3 } & NADPH $(\mathrm{pH} 7.0)$ & NADP $(\mathrm{pH} \mathrm{10.0)}$ \\
\hline Sorbose & $(100)$ & 0 \\
Glucose & 0 & 0 \\
Mannitol & 0 & 134 \\
Sorbitol & 0 & 134 \\
Fructose & 142 & 0 \\
Glycerol & 0 & 0 \\
Adonitol & 0 & 0 \\
Erythritol & 0 & 65.3 \\
Na-Gluconate & 0 & - \\
Ca-Idonate & 0 & - \\
Xylose & 0 & - \\
Xylulose & 25.7 & - \\
Ribulose & 2.4 & - \\
Tagatose & 0.8 & 0 \\
5-Keto-D-fructose & 86.8 &
\end{tabular}

a Each reaction rate with substrate is expressed as per cent of sorbose.

${ }_{b}$ Not tested.
$0.49 \mathrm{~mm}$ quinine (Table II).

Substrate specificity. The relative activities of the purified enzyme for various substrates were surveyed and are listed in Table III. L-Sorbose reductase from G. melanogenus N44-1 had a high rate of activity to reduce L-sorbose to D-sorbitol and to oxidize Dsorbitol to L-sorbose in the presence of NADPH, but NADH did not work as a cofactor for this reaction. In addition, D-fructose, 5-keto-D-fructose, D-xylulose, Dribulose, and D-tagatose were found to be substrates for L-sorbose reductase. This enzyme also oxidized D-mannitol and erythritol.

Identification of reduction and oxidation products. The reaction mixture $(1 \mathrm{ml})$ containing $50 \mathrm{~mm}$ each of L-sorbose, D-fructose and 5 -keto-D-fructose, and $0.28 \mathrm{~mm}$ of NADPH was incubated for $30 \mathrm{~min}$ in $\mathrm{pH} 7.0$ buffer (100 mm potassium phosphate) at $30^{\circ} \mathrm{C}$ with about 4.4 units of the purified enzyme. On the other hand, the reaction mixture $(1 \mathrm{ml})$ consisting of $40 \mathrm{~mm}$ each of D-sorbitol and D-mannitol and $0.28 \mathrm{~mm}$ of NADP was incubated for $30 \mathrm{~min}$ in $\mathrm{pH} 10.0$ buffer $(100 \mathrm{~mm}$ $\mathrm{Na}_{2} \mathrm{CO}_{3}-\mathrm{NaHCO}_{3}$ ) at $30^{\circ} \mathrm{C}$ with about 4.4 units of the purified enzyme. After the reaction, as described in Materials and Methods, the products were identified TLC and GLC (data not shown). L-Sorbose, D-fructose, and 5-ketoD-fructose were reduced to D-sorbitol, Dmannitol, and D-fructose, respectively, in the presence of NADPH. On the other hand, D-sorbitol and D-mannitol were oxidized to

Table IV. Apparent Michaelis Constants FOR VARIOUS SUBSTRATES

\begin{tabular}{lrc}
\hline Substrate & $\mathrm{pH}$ & $K m(\mathrm{M})$ \\
\hline L-Sorbose $^{a}$ & 7.0 & $3.28 \times 10^{-1}$ \\
D-Fructose $^{a}$ & 7.0 & $1.60 \times 10^{-1}$ \\
D-Sorbitol $^{a}$ & 10.0 & $1.67 \times 10^{-1}$ \\
D-Mannitol $^{a}$ & 10.0 & $7.30 \times 10^{-3}$ \\
NADPH $^{b}$ & 7.0 & $1.11 \times 10^{-4}$
\end{tabular}

a. NADPH was used as cofactor for L-sorbose and $D$-fructose, and NADP for D-sorbitol and Dmannitol.

$b$ The assay was done in the presence of $490 \mathrm{~mm}$ L-sorbose. 
L-sorbose and D-fructose respectively in the presence of NADP. However, the oxidation of $D$-fructose was not observed in the presence of NADP.

Effects of substrate concentration on reaction rate. The effects of substrate concentration on the enzyme activity were tested. Apparent Michaelis constants for various substrates were calculated $^{9)}$ and are summarized in Table IV. It was found that the affinity of the enzyme in the presence of NADP was highest for D-mannitol among all the carbohydrates tested.

\section{Discussion}

We purified and characterized the NADPHlinked L-sorbose reductase of $G$. melanogenus N44-1, which was one of the reductases functioning in the metabolic pathway of $2 \mathrm{KGA}$ production from D-sorbitol or L-sorbose (Fig. 1). This enzyme was apparently different from other, reductases such as L-sorbosone and $2 \mathrm{KGA}$ reductase because it was not active in the reduction of $\mathrm{L}$-sorbosone and $2 \mathrm{KGA}$. The L-sorbose reductase with regards to its function can also be called an oxidoreductase because it catalyzes not only the reduction of $\mathrm{L}$-sorbose and D-fructose in the presence of NADPH but also the oxidation of D-sorbitol and D-mannitol in the presence of NADP as illustrated below:

$\begin{aligned} & \mathrm{D}-\text { Sorbitol }+\mathrm{NADP} \\ & \text { (D-mannitol) }\end{aligned} \underset{\text { pH 7.0 }}{\stackrel{\mathrm{pH} 10.0}{\rightleftarrows}} \mathrm{L}-$ Sorbose $+\mathrm{NADPH}+\mathrm{H}^{+}$

Optimum pHs were around 10.0 for the forward reaction and 7.0 for the reverse reaction.

Here we report a purification scheme of NADP-linked L-sorbose reductase from $G$. melanogenus, an enzyme active in the catalysis of D-sorbitol and D-mannitol. Tsukada and Perlman ${ }^{10)}$ have reported that the cell-free extract of $G$. melanogenus IFO 3293 have activity to convert L-sorbose to D-sorbitol and vise versa in the presence of $\operatorname{NADP}(\mathrm{H})$; they postulated that the enzyme is a coenzymedependent dehydrogenase and that the reaction favors the conversion from L-sorbose to D-sorbitol. According to Widmer ${ }^{11}$ and
Cummins et al., ${ }^{12,13)}$ three enzymes for the oxidation of D-sorbitol were found in the cell-free extract of $A$. suboxydans (syn. $G$. suboxydans). In addition to a dehydrogenase in the membrane fraction, ${ }^{14,15)}$ there were two enzymes in the soluble fraction; one catalyzes D-fructose formation in the presence of NAD and another catalyzes L-sorbose formation in the presence of NADP. However, the NADPlinked D-sorbitol dehydrogenase has not been purified because of its instability. Shaw ${ }^{16)}$ and Kersters et al., ${ }^{17)}$ have reported on NADPlinked D-mannitol dehydrogenase activity in cell extracts of A. suboxydans TACC621 (syn. G. suboxydans) and G. suboxydans strain SU, respectively. Yamada et al. ${ }^{18)}$ reported the purification and properties of NADP-linked 5-keto-D-fructose reductase of G. albidus IFO 3250 , but the substrate specificity of the enzyme was significantly different from ours, namely 5-keto-D-fructose reductase is not active in the catalysis of L-sorbose.

Comparing the catalytic properties of the enzymes described above with ours, we suggest that our L-sorbose reductase is in fact the same as NADP-linked D-sorbitol dehydrogenase and D-mannitol dehydrogenase as described by Widmer, Cummius, Shaw, and Kersters et al.

In the metabolic pathway for the production of $2 \mathrm{KGA}$, our enzyme was thought to function mainly as a reductase in vivo during the fermentation of $2 \mathrm{KGA}$, which means that the conversion of L-sorbose to D-sorbitol is the main function of the enzyme as described by Tsukada and Perlman ${ }^{10)}$ because the reductive activity of the enzyme was higher than the oxidative activity at the $\mathrm{pH}$ between 5 and 7 as shown in Fig. 4, which was the $\mathrm{pH}$ range suitable for cell growth and $2 \mathrm{KGA}$ production as described in a previous paper, ${ }^{1)}$ and in addition, the intracellular $\mathrm{pH}$ of the acetic acid bacteria is thought to be around 7.0. The products formed from L-sorbose by the reductive function of the enzyme are $\mathrm{D}$-sorbitol and NADP.

In the $2 \mathrm{KGA}$ fermentation from L-sorbose or D-sorbitol, our mutants of G. melanogenus, as previously reported, ${ }^{1)}$ about $40 \%$ of both 
substrates added was wasted without contributing to $2 \mathrm{KGA}$ formation. L-Sorbose was considered to be dissimilated finally to $\mathrm{CO}_{2}$ via D-sorbitol and then via the pentose cycle. In fact, a blocked mutant of L-sorbose reductase could not grow on L-sorbose as a sole carbon source. In this context, the L-sorbose reductase seems to be the first-step enzyme for the dissimilation of L-sorbose in our microorganisms.

Acknowledgment. The authors thank Mr. M. Tazoe and Ms. S. Someha for providing us with the blocked mutant of L-sorbose reductase.

\section{References}

1) T. Sugisawa, T. Hoshino, S. Masuda, S. Nomura, Y. Setoguchi, M. Tazoe, M. Shinjoh, S. Someha and A. Fujiwara, Agric. Biol. Chem., 54, 1201 (1990).

2) T. Sugisawa, T. Hoshino and A. Fujiwara, Agric. Biol. Chem., 55, 363 (1991).

3) T. Hoshino, T. Sugisawa and A. Fujiwara, Agric. Biol. Chem., 55, 665 (1991).

4) T. Hoshino, T. Sugisawa, M. Tazoe, M. Shinjoh and A. Fujiwara, Agric. Biol. Chem., 54, 1211 (1990).
5) M. Shinjoh, Y. Setoguchi, T. Hoshino and A. Fujiwara, Agric. Biol. Chem., 54, 2257 (1990).

6) B. J. Davis, Ann. N.Y. Acad. Sci., 121, 404 (1964).

7) K. Weber and M. Osborn, J. Biol. Chem., 244, 4406 (1969).

8) K. Weber and D. J. Kuter, J. Biol. Chem., 246, 4504 (1971).

9) H. Lineweaver and D. Bruk, J. Am. Chem. Soc., 56, 658 (1934).

10) Y. Tsukada and D. Perlman, Biotech. and Bioeng., 14, 799 (1972).

11) C. Widmer, T. E. King and V. H. Cheldelin, J. Bacteriol., 71, 737 (1956).

12) J. T. Cummins, T. E. King and V. H. Cheldelin, $J$. Biol. Chem., 224, 323 (1957).

13) J. T. Cummins, V. H. Cheldelin and T. E. King, $J$. Biol. Chem., 226, 301 (1957).

14) E. Shinagawa, K. Matsushita, O. Adachi and M. Ameyama, Agric. Biol. Chem., 46, 135 (1982).

15) C. A. Baker and G. W. Claus, FEMS Microbiol. Lett., 18, 123 (1983).

16) D. R. D. Shaw, Biochim. Biophys. Acta, 113, 608 (1966).

17) K. Kersters, W. A. Wood and J. De Ley, J. Biol. Chem., 240, 965 (1965).

18) Y. Yamada, K. Aida and T. Uemura, J. Biochem., 61, 803 (1967). 